\title{
Dynamics of Phosphorus, Nitrate and Organic Carbon in the Mangrove Swamps of Devgad and Phanase Estuaries of Coastal Maharashtra
}

\author{
Nisha R. Mugade ${ }^{\# 1}$, Jagdish B. Sapkale ${ }^{* 2}$ \\ ${ }^{1}$ Ph.D. Scholar, Department of Geography, Shivaji University, Kolhapur, Maharashtra, India \\ ${ }^{1}$ E-mail-nrm.geo.rs@unishivaji.ac.in \\ ${ }^{2}$ Assistant Professor, Department of Geography, Shivaji University, Kolhapur, Maharashtra, India. \\ ${ }^{* 2}$ Corresponding Author : E-mail- sapkalejagdish@gmail.com
}

\begin{abstract}
Mangrove is natural vegetation, which performs its defensive role for the protection of coastal environment. Increasing population, rapid growth of industrial and urban sectors are directly or indirectly influencing on the mangrove ecosystem. The physical and chemical properties of soil were analyzed from the mangrove swamps of Phanase and Devgad. The study reveals that, variation in mangrove species and characteristics of Phanase are more than the mangroves of Devgad. Comparatively there is a drastic change in the characteristics of soil properties in terms of organic carbon, $\mathrm{pH}$, salinity, nitrate and phosphorus for the both mangroves sites. Water pollution leads to degradation of wetlands and wetland ecosystem. The present study was carried out to examine the physicochemical characteristics of sediments in the Phanase and Devgad estuaries, coast of Maharashtra. pH was diverse from 6.06 - 8.44 at Phanase and 6.5 - 8.12 at Devgad during post monsoon season and 5.6 - 8.5 at Phanase and 6.9 - 8.7 at Devgad during pre-monsoon. Salinity was ranged from $0.03-5.93 \mathrm{dS} / \mathrm{m}$. Variation in organic carbon content was from $0.42 \%$ to $3.54 \%$ at both estuaries. Concentrations of nutrients during post and premonsoon season viz. Phosphorus $(4.28-261.56 \mathrm{~kg} / \mathrm{hec})$ and $(11.79-98.45 \mathrm{~kg} / \mathrm{hec})$ respectively, during premonsoon season nitrate $(0.117-1.295 \mathrm{gm} / \mathrm{kg})$ also varied independently.
\end{abstract}

Keyword - Mangroves, ecosystem, diversity, physicochemical characteristics, Phosphorus, Nitrate, Organic Carbon.

\section{INTRODUCTION}

Mangrove soils are marine alluvium which is transported and deposited along the estuaries, with the fluvial processes of river and sea water. Most of the mudflat/ mangrove swamp are found at the mouth of estuary. Mangrove vegetation is the associated part of marine ecosystem which plays its significant role for maintaining the balance between many aspects of aquatic environment. There is an interrelationship between biotic and abiotic factors in the mangrove ecosystem. The organic matter is provided by the mangroves to the soil, the degraded leaves of the mangroves increased the organic content of the soil. The soils of mangrove swamps are enriched with higher amount of fine clay and organic carbon. The soil structure and specially salinity of the soil are the main factors, controlling the distribution of mangroves. Large difference occurs in mangroves forest with respect to Salinity, pH, Organic material, carbon etc. Different soil properties influences on mangrove species and forest status. Soil plays important role in mangrove growth. Mangroves required fine sediment to set their roots. Besides that soil provide nutrients to the mangroves. Soil analysis can provide important information about physical and chemical properties, fertility status of the soil. Physico-chemical parameters are influence on the diversity of species, pattern, breeding and metabolism activities. Hence, the present study was carried out to investigate the changes of physico-chemical parameters and nutrients in the Phanase and Devgad estuaries, coastal Maharashtra.

The mangrove ecosystem is characterised with the varieties of mangrove species in the form of trees and shrubs that is found in intertidal zones of tropical and subtropical areas [1,2]. The health of mangrove species and its growth also depends on differentiate oxygen levels in the soils and water of the mangrove swamps. The contaminated soil with the high levels of toxic ammonia and lower level of oxygen also affects on the mangrove growth and resulting for the decrease in mangrove species [3].

$\mathrm{pH}$ is most common factor in soil and water. $\mathrm{pH}$ is used to measure acidic and alkaline solution. It is measured a scale from 0-14. When $\mathrm{pH}$ is 7 it is neutral, less than 7 it is acidic and greater than 7 it is basic [4]. $\mathrm{pH}$ value above 7.5 results less availability of iron, manganese, copper, zinc into the mangrove plant. In the form of insoluble hydroxides some essential nutrients added due to extreme in $\mathrm{pH}$. For the maximum growth rate of the seedling soil $\mathrm{pH}$ should be between 5.16 to 7.72 . This $\mathrm{pH}$ level nutrient availability and useful microbial activity is favorable for growth of Avicennia alba seedling germination [5]. Minimum $\mathrm{pH}$ was 
recorded during the month of February and maximum during month of May. Higher value of $\mathrm{pH}$ during summer was due to the uptake of $\mathrm{CO} 2$ by photosynthesizing organisms. In January to March $\mathrm{pH}$ was low due to the influence of fresh water inflow and dilution of sea water, low temperature [6]. $\mathrm{pH}$ in soil negatively correlated with the rainfall, nitrate and phosphate in water. Salinity showed a significant positive correlation with temperature. In mangroves of Kachchh salinity was high during summer due to evaporation and low during monsoon season due to rainfall [7].

Salinity in water of estuaries, backwater and mangroves are influenced by fresh water which comes from land run offs and also by monsoon and tidal influence. Salinity shows positive correlation with temperature and salinity was mainly influenced by the monsoon and entry of saline water when sand bar opens [8]. Among the environmental parameter in the marine environment salinity is one of the most fluctuating parameter. Salinity is higher during summer and low during monsoon season. In Karankadu mangrove forest salinity varied from 34.9 to 39.3 ppt [9]. Salinity has an effect on the accumulation of trace metals. It is found that salinity had an effect on the accumulation characteristics of metals in the tissues of marine species like, N. Crepidularia [10]. In the Pondicherry mangroves, water and sediment salinity ranged between 6.36 to 36.77 ppt. Positive correlations seen between temperature and salinity and that indicates in the mangroves environment salinity was largely influenced by temperature. According to topography of the particular area salinity varies, due to high and low tide i.e. fresh and saline water inflow also varies [11]. In the research study of Muthupettai mangroves the salinity has been found with a range from $16 \%$ to $35 \%$. The minimum salinity was recorded during monsoon and the maximum in summer and fluctuations in salinity observed may be due to rainfall and monsoonal flood [12].

Content of organic carbon in soil was decreases with increase in depth. Higher value of organic carbon was recorded during post monsoon. For the growth of cellulose decomposing bacteria organic carbon content in soil is significant. "Organic carbon from the leaves, wood from forest and other organic dead or waste products from other living creatures are easily degraded by cellulose degrading bacteria in the mangrove soil because they are the most dominating group of microbes prior to fungi”[13]. Because of tidal activity low organic activity is recognized to the re-suspension of organic water column [14]. In arid zone mangroves of Kachchh-Gujarat organic carbon was varied from $0.29 \%$ to $2.56 \%$. Distribution of sediment is correlated with the distribution of total organic carbon. The higher values of nitrogen are releases from the decay of a large number of phytoplankton and organic matter [15]. At Coringa Wild Life Sanctuary (CWS) and Seethanagaram Mangroves' Area (SMA) of Andhra Pradesh in South India has shown 4.28\% and 3.12\% organic carbon respectively. Higher value of organic carbon was seen due to the organic carbon inputs from terrestrial and aquatic origins. Organic carbon was high during monsoon and low during winter season [16]. Mangrove Sediment at Different Depths in Southeastern Brazil illustrate that organic carbon at the mouth of the sea i.e. near to sea is $3.5 \%$ it decreased in the middle parts of the mangroves and again increased up to $12.5 \%$ in the land area[17].

The inorganic phosphorus and nitrogen are the nutrients which are abundantly present in the soil of mangroves due to the biotic and biological processes. The nutrients are benefits to the mangrove growth and recycled in mangrove ecosystem. The mangrove swamps are the deposits of various nutrients. The quantity of phosphorus increase in the mangrove swamps and during monsoon season some of the nutrient quantity migrated to the adjoining areas through water ways. Economic valuation of soil nutrients from the mangrove wetlands have also been estimated [18]. Concentration of phosphorus decreases with increase in depth [13]. The correlation between parameter like bacterial colonies and physicochemical reveals that organic matter and carbon, available phosphorus in the soil were negatively correlated. Content of phosphorus in the soil is maximum during post monsoon and minimum in pre-monsoon season [9]. From urban areas to the mangrove swamps the inputs from different anthropogenic sources like run-offs from agriculture and aquaculture with its waste water disposal increases amount of organic material. This is resulting for increase the rate of decomposition of organic matter by increasing bacterial growth but that leads to increase proportion of phosphorus in the soils [19].

Nitrate is easily dissolves in water and one of the stable nutrients over a wide range of environmental conditions. Nitrate easily transport through streams and groundwater. Microscopic plants and animals that live in water i.e. aquatic plants and algae used nitrate as their food and these all are eaten by fish [20]. Mainly the variation of physico-chemical parameter is depends on monsoon rain. In the environment nitrate is present naturally and it is a product of ammonia, this ammonia released by the decomposed organic material [4]. In mangrove region of east Godavari district, nitrate in surface water was $45.4 \mathrm{mg} / \mathrm{l}$ and $47.9 \mathrm{mg} / \mathrm{l}$ during pre and post monsoon. A higher value of Nitrate shows the discharge of agricultural runoff into the water sources [21]. In the Pinchavaram mangroves, southeast coast of India nitrate varied from 0.35 to $40.7 \mathrm{mg} \mathrm{l-1}$ and that was a result of the over use of fertilizers and biological activities [22]. 


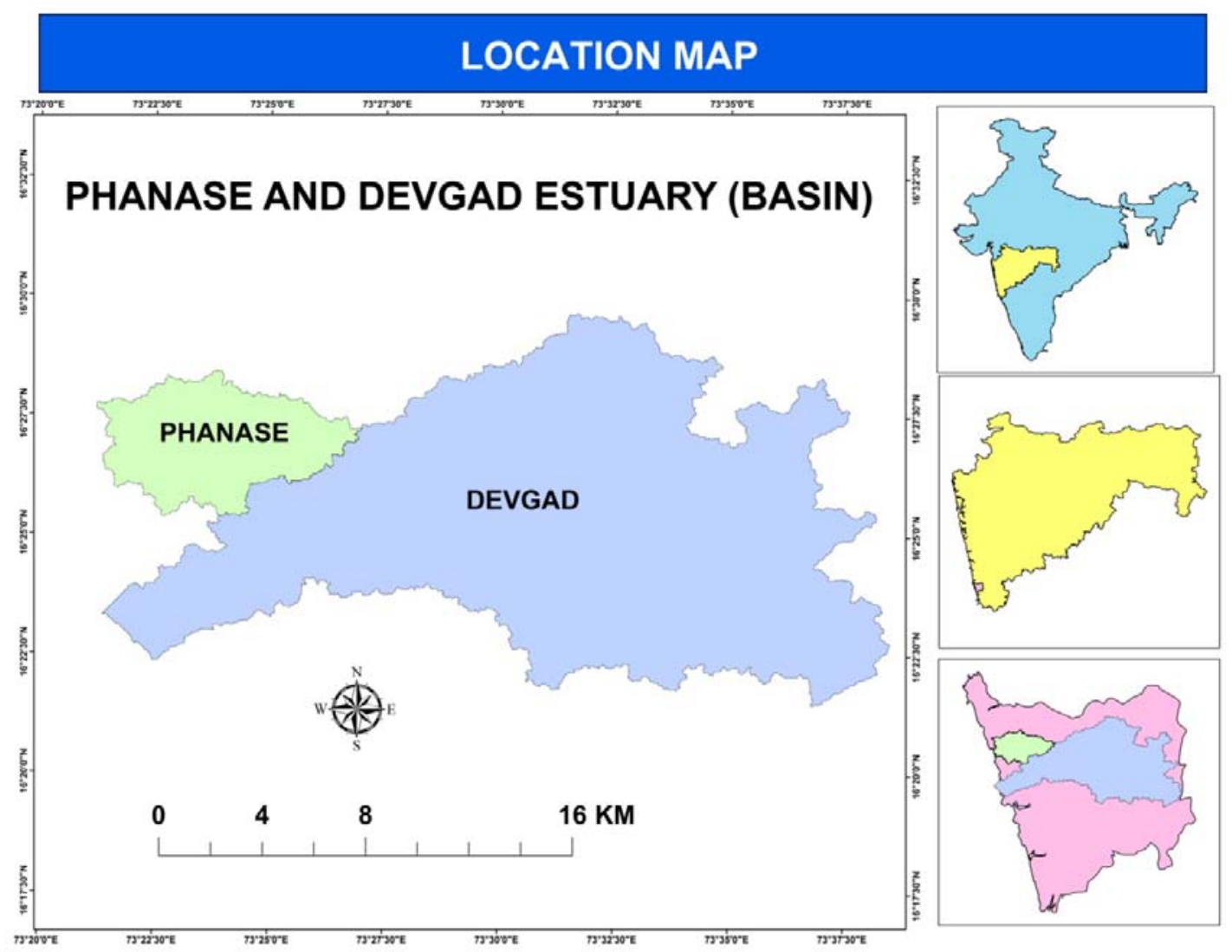

Fig. 1. Location map

\section{MATERIALS AND METHODS}

Soil samples were collected from the mangrove swamps of Phanase and Devgad estuaries. For the sample collection each estuary were divided into three zones i.e. Mouth zone, middle zone and upstream zone. Soil samples were collected from both banks of the estuaries. Therefore ' $L$ ' and ' $R$ ' codes have given to the Left and Right bank respectively. Mouth zone is considered as 1 and middle and upstream zones 2 and 3 correspondingly. So, samples were securely labelled with a sample codes at the sample site with reference to their location i.e. Soil samples along the 'Phanase' estuary coded With 'PH' and for left bank and zone use L1, L2, L3 as for right bank R1, R2, R3. Soil samples were taken into the $1 \mathrm{~kg}$ polythene bag [23]. pH was measured using pH meter (Thermo scientific ORION STAR A211). Organic Carbon, Phosphorus in soil samples were analysed using Spectrophotometer (LABTRONICS MODEL LT-39).

\section{RESULT AND DISCUSSION}

Practically, it has noticed that degradation of mangroves in the coastal tracts of Rajapur and Devgad tehsils are the result of consumption of mangrove for various purposes like construction (building material), agriculture, fishing, fuel wood, disposal of waste water etc $[24,25]$. Therefore, the damage of mangroves are simultaneously affecting the distribution patterns of sediment nutrients of mangroves and also alters the processes of nutrients and metals consumption in the ecosystem. In the present research work the differentiate patterns of $\mathrm{pH}$, salinity, organic carbon, phosphorus and nitrate have seen with diverse magnitudes.

pH -

In case of Phanase estuary, during post-monsoon season variations in $\mathrm{pH}$ value have observed. $\mathrm{pH}$ was slightly higher in upstream zone than middle zone. Values were 8.09 (i.e. PH-R2) and 5.78 (i.e. PH-L2); whereas the values for locations of upstream parts were 7.39 and 6.06. Toward mouth of the estuary $\mathrm{pH}$ was increases up to 8.44 (L1) and $7.72 \mathrm{R} 1$ ). During pre-monsoon there was increase in $\mathrm{pH}$ value towards upstream part of the estuary. Lowest $\mathrm{pH}$ value i.e. 5.6 has observed at mouth zone and it was increased up to 6.5 and 7.6 in middle and 7.8 and 8.5 in the upstream (Table 1 and 2). The waste disposals and degradation of mangroves (Fig 2 and 3) also affects on the nutrients function. The basin area of Devgad estuary is larger in size than the Phanase Estuary basin. Soil sample was collected from the left bank of Devgad mouth zone of the estuary only because in the right bank there is rocky headland. There was increase in $\mathrm{pH}$ towards upstream during postmonsoon. $\mathrm{pH}$ ranged from 6.5 to 8.12 , in this $6.5 \mathrm{pH}$ value recorded from mouth and $8.12 \mathrm{pH}$ value from 
upstream zone. During pre-monsoon in Devgad estuary $\mathrm{pH}$ value varies from 6.9 - 8.7. In this $8.7 \mathrm{pH}$ value was documented from mouth zone. In the middle zone of estuary $\mathrm{pH}$ was ranged from 7 - 8.6 and in upstream shows 6.9 and 7.8 (Table 3 and 4).

\section{Salinity -}

In case of Phanase estuary soil salinity in the mouth and upstream zone were higher than middle zone. Soil salinity varied from 3.97 to $5.93 \mathrm{dS} / \mathrm{m}$ in respect of mouth and upstream zone. In middle zone soil salinity was ranged from 0.7 to $3.66 \mathrm{dS} / \mathrm{m}$. Phanase estuary shows variations in soil salinity during pre-monsoon. In mouth zone soil salinity was very low i.e. $0.03 \mathrm{dS} / \mathrm{m}$. In the middle zone soil salinity was ranged from 0.31 $5.63 \mathrm{dS} / \mathrm{m}$ and in the upstream $2.02-4.46 \mathrm{dS} / \mathrm{m}$. Soil salinity of Devgad estuary was increased towards upstream zone during post-monsoon. In the mouth zone soil salinity was $0.89 \mathrm{dS} / \mathrm{m}$, in middle zone it was varied from 0.42-2.14 dS/m and in upstream it was increased up to $1.55-4.41 \mathrm{dS} / \mathrm{m}$. During pre-monsoon Devgad estuary shows increase in soil salinity towards upstream area. In the mouth zone soil salinity was 1.77 $\mathrm{dS} / \mathrm{m}$ but in the middle zone it was increases up to $3.15 \mathrm{dS} / \mathrm{m}$ and towards upstream it was recorded as 2.6 to $5.42 \mathrm{dS} / \mathrm{m}$. The salinity tolerance species of mangroves can survive in the middle part of Devgad with higher values of salinity.

\section{Organic Carbon -}

In Phanase organic carbon in soil was varied from zone to zone during post-monsoon. It was varied from $0.87-2.07 \%$ in the mouth zone. $0.82-0.9 \%$ (R2 to L2) organic carbon was recorded in the sediments of middle part. In the upstream zone organic carbon in soil was $0.45-2.49 \%$. During pre-monsoon range of the organic carbon was increased towards upstream zone. It was 0.51 and $0.56 \%$ at the mouth zone and it continuously increased up to $0.82-3.42 \%$ towards upstream. Devgad estuary shows highest organic carbon value in soil in the middle zone of estuary i.e. 1.49-3.54\%, this indicates the higher nutrition capacity for the healthy growth of mangroves in this part. In the mouth and upstream zone organic carbon in soil was 0.89 and 1.15$1.22 \%$ respectively. During pre-monsoon organic carbon in soil was varied from $0.6-3.47 \%$ at the upstream zone, it was decreased up to $0.69-1.17$ at the middle and again increased up to $1.5 \%$ at the mouth zone .

\section{Phosphorus -}

Soils of the Phanase estuary have different amount of phosphorus during post and pre monsoon at the left and right bank. During post-monsoon phosphorus was ranged from 11.52-76.39, 60.5-20.42 and 17.45-8.29 $\mathrm{kg} / \mathrm{hec}$ at the mouth, middle and upstream zones respectively. At the mouth, middle and upstream zones phosphorus was varied from 11.79-64.87, 12.18-46.93 and 61.9-22.39 kg/hec during pre-monsoon. Devgad estuary had higher proportion of phosphorus during post-monsoon in soil as compare to mouth zone. It was $263.56 \mathrm{~kg} / \mathrm{hec}$ and during pre-monsoon it falls down to $98.45 \mathrm{~kg} / \mathrm{hec}$. But in case of middle and upstream zones the portion of phosphorus in soil was rises in the pre-monsoon season. During post-monsoon phosphorus was $18.11-10.87$ and $4.61-4.28 \mathrm{~kg} / \mathrm{hec}$ and in pre-monsoon it was $65.53-54.99$ and $30.62-38.2 \mathrm{~kg} / \mathrm{hec}$ in the middle and upstream zones respectively.

\section{Nitrate -}

Phanase estuary had higher proportion of nitrate at the mouth zone. It was ranged from $0.112 \mathrm{mg} / \mathrm{kg}$ and $1.295 \mathrm{mg} / \mathrm{kg}$ at the left and right banks respectively during pre-monsoon season. At the middle zone, amount of nitrate was decreased as compared to mouth zone (range was $0.132-0.135 \mathrm{mg} / \mathrm{kg}$ at left and right bank respectively). Towards upstream zone nitrate content in the sediment of left bank was $0.117 \mathrm{mg} / \mathrm{kg}$ and at the right bank it was little bit higher $(0.146 \mathrm{mg} / \mathrm{kg})$. At the mouth zone of Devgad estuary the nitrate in the soil of left bank was $0.120 \mathrm{mg} / \mathrm{kg}$. Towards middle zone nitrate amount in soil slightly increases i.e. was $0.189-0.171$ $\mathrm{mg} / \mathrm{kg}$ at the left and right bank respectively. At the upstream zone nitrate in the soil of left bank was1.202 $\mathrm{mg} / \mathrm{kg}$ and it was highest value in the estuary. At the right bank it was $0.153 \mathrm{mg} / \mathrm{kg}$. he order. The negative relationship has detected between stream order and numbers of stream to the respective order.

TABLE I. Physico-chemical analysis of soil samples in Phanase Estuary (Post-monsoon- 2014)

\begin{tabular}{|c|c|c|c|c|c|c|}
\hline \multirow{2}{*}{ Parameter } & \multicolumn{7}{|c|}{ Phanase Estuary } \\
\cline { 2 - 7 } & L1 & R1 & L2 & R2 & L3 & R3 \\
\hline pH & 8.44 & 7.72 & 5.78 & 8.09 & 7.39 & 6.06 \\
\hline Salinity (dS/m) & 5.93 & 3.97 & 0.7 & 3.66 & 5.98 & 0.56 \\
\hline Organic Carbon\% & 0.87 & 2.07 & 0.9 & 0.82 & 2.49 & 2.45 \\
\hline Phosphorus(kg/hec) & 11.52 & 76.39 & 60.5 & 20.42 & 17.45 & 8.29 \\
\hline
\end{tabular}


TABLE III. Physico-chemical analysis of soil samples in Phanase Estuary (Pre-monsoon- 2015)

\begin{tabular}{|c|c|c|c|c|c|c|}
\hline \multirow{2}{*}{ Parameter } & \multicolumn{7}{|c|}{ Phanase Estuary } \\
\cline { 2 - 7 } & L1 & R1 & L2 & R2 & L3 & R3 \\
\hline pH & 5.6 & 6.6 & 7.6 & 6.5 & 7.8 & 8.5 \\
\hline Salinity (dS/m) & 0.03 & 0.36 & 5.63 & 0.31 & 4.46 & 2.02 \\
\hline Organic Carbon\% & 0.51 & 0.56 & 2.66 & 1.05 & 0.82 & 3.42 \\
\hline Phosphorus(kg/hec) & 11.79 & 64.87 & 12.18 & 46.93 & 61.9 & 22.39 \\
\hline Nitrate (gm/kg) & 0.122 & 1.295 & 0.132 & 0.135 & 0.117 & 0.146 \\
\hline
\end{tabular}

TABLE IIIII. Physico-chemical analysis of soil samples in Devgad Estuary (Post-monsoon - 2014)

\begin{tabular}{|c|c|c|c|c|c|c|}
\hline \multirow{2}{*}{ Parameter } & \multicolumn{7}{|c|}{ Devgad Estuary } \\
\cline { 2 - 7 } & L1 & R1 & L2 & R2 & L3 & R3 \\
\hline $\mathbf{p H}$ & 6.5 & NC & 7.18 & 6.85 & 8.12 & 7.46 \\
\hline Salinity (dS/m) & 0.89 & NC & 2.14 & 0.42 & 1.55 & 4.41 \\
\hline Organic Carbon \% & 0.89 & NC & 3.54 & 1.49 & 1.15 & 1.22 \\
\hline Phosphorus(kg/hec) & 263.56 & NC & 18.11 & 10.87 & 4.61 & 4.28 \\
\hline
\end{tabular}

NC*- Not Collected

TABLE IVII. Physico-chemical analysis of soil samples in Devgad Estuary (Pre-monsoon- 2015)

\begin{tabular}{|c|c|c|c|c|c|c|}
\hline \multirow{2}{*}{ Parameter } & \multicolumn{7}{|c|}{ Devgad Estuary } \\
\cline { 2 - 7 } & L1 & R1 & L2 & R2 & L3 & R3 \\
\hline pH & 8.7 & NC & 7.0 & 8.6 & 7.8 & 6.9 \\
\hline Salinity (dS/m) & 1.77 & NC & 3.1 & 3.15 & 2.6 & 5.42 \\
\hline Organic Carbon\% & 1.5 & NC & 0.69 & 1.17 & 3.47 & 0.6 \\
\hline Phosphorus(kg/hec) & 98.45 & NC & 65.53 & 54.99 & 30.62 & 38.2 \\
\hline Nitrate (gm/kg) & 0.120 & NC & 0.189 & 0.171 & 1.202 & 0.153 \\
\hline
\end{tabular}

NC*- Not Collected

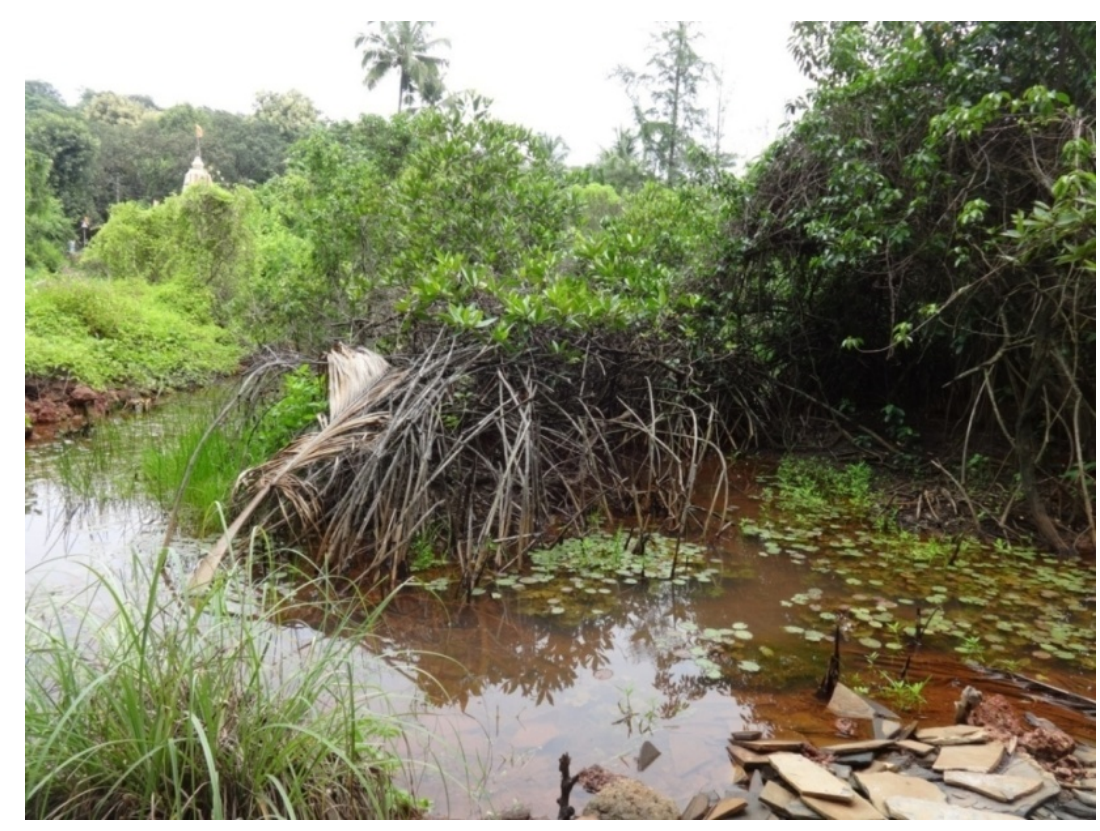

Fig. 2. Mangroves degradation at Phanase Estuary 


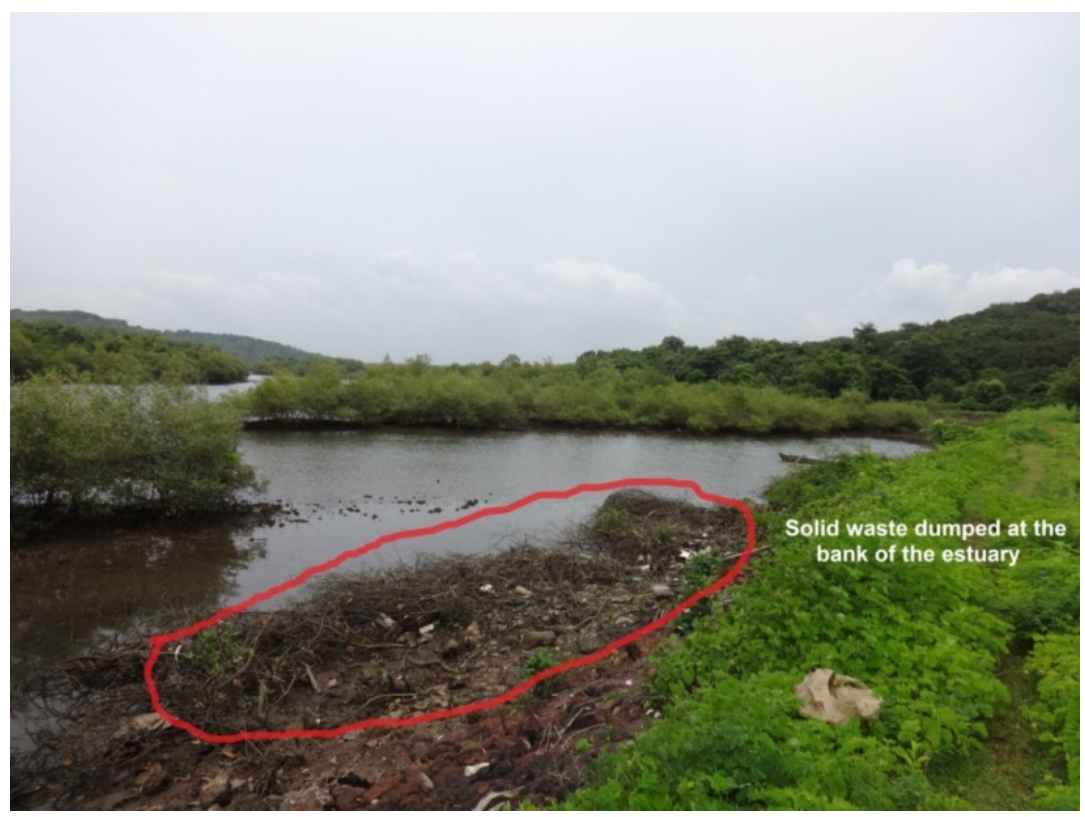

Fig. 3. Solid waste dumped at the left bank of the Phanase Estuary

\section{CONCLUSION}

Many studies have been undertaken to conserve the mangrove vegetation, but there is a need to conserve the mangrove ecosystem in a proper and scientific way. The participatory involvement of local native people is very significant. There must be inputs from the all scientific groups with their updated knowledge. Collaborative management practice should be introduced. The research community should consider the various aspects of the mangroves, because there is an impact of:- climate change on mangroves, impact of soil characteristics, tidal processes, and many others. Continuous monitoring of mangroves through recent techniques of remote Sensing is more appreciable. One can assess the growth and degradational rate of mangroves continuously with this techniques, will support for making some concrete plans and policies to protect the mangroves. Mangroves fulfill many extremely important protective, productive, and social functions. Increased population pressures in coastal areas and lack of awareness about importance of mangroves have lead to large scale conversion of mangroves to other uses. Salinity is one of the most important factors which strongly influence the abundance and distribution of the mangrove estuarine environment. Higher salinity recorded during post monsoon season with a value of 5.93 at Phanase and 5.42 at Devgad estuary during premonsoon. Salinity range on an average was lower during pre monsoon as compare to post monsoon season. Influx of fresh water through heavy rainfall and large quantity of fresh water inflow is high during monsoon so that affect on the salinity level. At the mouth of the estuary mangroves are not grows due to the higher salinity. Higher salinity rate causes threat to mangroves. Water $\mathrm{pH}$ was alkaline throughout the year at all the sample sites in study area, which is a characteristic feature of marine environment. The physical and chemical properties of soil and water were analyzed from the mangrove swamps of Phanase and Devgad. The study reveals that, variation in mangrove species and characteristics of Phanase are more than the mangroves of Devgad. Comparatively there is a drastic change in the characteristics of soil and water properties in terms of organic carbon, $\mathrm{pH}$, salinity, nitrate and phosphorus for the mangroves sites. The organic matter is provided by the mangroves to the soil, the degraded leaves of the mangroves increased the organic content of the soil. The soils of mangrove swamps are enriched with higher amount of fine clay and organic carbon. Nitrate and Phosphorus was resulting due to the over use of fertilizers and biological activities.

\section{REFERENCES}

[1] G. Naidoo, F. Raiman, “Some physical and chemical properties of mangrove soils at Sipingo and Mgeni,” Natal. S.-Afr. Tydskr. Plantk., vol. 1(4), pp.1-6, 1982.

[2] N.R. Mugade, J.B. Sapkale, “A review of mangrove conservation studies in Maharashtra, India,” International Journal of Engineering and Technical Research (IJETR)., vol. 2(11), pp. 338-341, 2014

[3] R. J. Diaz, R. Rosenberg, "Marine benthic hypoxia: a review of its ecological effects and the behavioral responses of benthic macro fauna," Oceanography and Marine biology:An Annual review., vol. 33, pp. 245-303, 1995.

[4] S.S. Sagar, R.P. Chavan, C.L. Patil, D.N. Shinde, S.S. Kekane, "Physico-chemical parameters for testing of water- A review," International Journal of Chemical Studies., vol. 3(4), pp. 24-28, 2015.

[5] Z. K. Lim, N.H.P. Genevieve, M.M. Goh, T.Y.K. Loh, "Investigating the effect of soil ph on the germination of Avicennia alba seedlings,” Report. Nature Society (Singapore)., 2012.

[6] P.Soundarapandian, T. Premkumar, G.K. Dinakaran, "Studies on the physico-chemical characteristics and nutrients in the Uppanar estuary of Cuddalore, south east coast of India,” Current Research Journal of Biological Sciences., vol. 1(3), pp.102-105, 2009. 
[7] A. Saravanakumar, M. Rajkumar, J. Sesh Serebiah, G.A. Thivakaran, "Seasonal variations in physico-chemical characteristics of water, sediment and soil texture in arid zone mangroves of Kachchh-Gujarat," Journal of Environmental Biology., vol. 29(5), pp. 725-732, 2008.

[8] A. Arumugam, S. P. Kumar, "Evaluation of physico-chemical parameters and nutrients in the mangrove ecosystem of Manakudy estuary, southwest coast of India,” International Journal of Latest Research in Science and Technology., vol. 3(6), pp. 205-209, 2014.

[9] A. Saseeswari, G. Kanimozhi, A. Panneerselvam, "Studies on physicochemical parameter and bacterial populations in sediment soil at Karankadu mangrove forest, Ramanathapuram (Dt), Tamil Nadu,” International Journal of Science, Environment and Technology., vol. 4(3), pp. 886 - 895, 2015.

[10] C. Palpandi, K. Kesavan, "Heavy metal monitoring using Nerita crepidularia-mangrove mollusc from the Vellar estuary, Southeast coast of India,” Asian Pacific Journal of Tropical Biomedicine., pp. S358-S367, 2012.

[11] P. Satheeshkumar, B.A. Khan, "Seasonal variations in physico-chemical parameters of water and sediment characteristics of Pondicherry mangroves,” African Journal of Basic \& Applied Sciences., vol. 1(1-2), pp. 36-43, 2009.

[12] G. Srilatha, B. Thilagavathi, D. Varadharajan, "Studies on the physico-chemical status of muthupettai mangrove, south east coast of INDIA,” Advances in Applied Science Research., vol. 3(1), pp. 201-207, 2012.

[13] S. Das, M. De, D. Ganguly, T. K. Maiti, A. Mukherjee, T.K. Jana, T.K. De, "Depth integrated microbial community and physicochemical properties in mangrove soil of Sundarban, India,” Advances in Microbiology., vol. 2, pp. 234-240, 2012.

[14] G. Jeyaba, S. Ramasamy, "Down core variation in sediment characteristics and trace element geochemistry of a core sample in Pichavaram mangrove area, Tamil Nadu, southeast coast of India,” Enviro Geo Chimica Acta., vol. 1(3), pp. 206-214, 2014A.

[15] H.R. Reddy Venkataswamy, V. Hariharan, "Distribution of nutrients in the sediments of the Netravathi-Gurupur estuary, Mangalore," Ind. J. Fish., vol. 33, pp. 123-126, 1986. In: A. Saravanakumar, M. Rajkumar, J. Sesh Serebiah, G.A. Thivakaran, "Seasonal variations in physico-chemical characteristics of water, sediment and soil texture in arid zone mangroves of Kachchh-Gujarat," Journal of Environmental Biology., vol. 29(5), pp. 725-732, 2008.

[16] Dogiparti, R. K. Kurapati, S. K. Duddu, "Comparison of selected soil chemical properties of two mangrove areas of east coast of Andhra Pradesh south India,” International Journal of Innovative Research in Science \& Engineering., vol. 2(5), pp. 319-328, 2014.

[17] L.W. Mendes, S.M. Tsai, "Variations of bacterial community structure and composition in mangrove sediment at different depths in southeastern Brazil,” Diversity., vol. 6, pp. 827-843 2014.

[18] P. Sreeja, V.V. Gilna, K.M. Khaleel, "Economic valuation of soil nutrients from the mangrove rich wetlands of Kannur district," Botany Research International., vol. 2 (1), pp. 27-29, 2009.

[19] G.Singh, R. Chauhan, R.K. Ranjan, M. Balakrishna Prasad, A.L. Ramanathan, "Phosphorus dynamics in mangroves of India," Current Science., vol. 108(10), pp. 1874-1881, 2015.

[20] R. Rajendran, A. Pandia Rajan, A. Sahaya Raja, V. Prathipa, M.S. Dheenadayalan, "Assessment of physico-chemical parameters of river Cauvery in and around Nerur,” Journal of Environmental Science and Pollution Research., vol. 1(1), pp. 17-19, 2015.

[21] B. V. Kumari, Y. L. N. Murthy, "An investigative study on hydro geochemistry of waters in Coringa mangrove region of east Godavari district,” International Journal for Innovative Research in Science \& Technology., vol. 2(1), PP. 98-107, 2015.

[22] A.L. Ramanathan, V. Subramanian, R. Ramesh, S. Chidambaram, A. James, "Environmental geochemistry of the Pichavaram mangrove ecosystem (tropical), southeast coast of India,” Environmental Geology., vol. 37 (3), pp. 223-233, 1999.

[23] S.S. Navami, D.S. Jaya, "Assessment of pollution stress on the physio-biochemical characteristics of mangrove species in AkkulamVeli Lake, south India,” Global Journal of Environmental Research., vol. 7(2), pp. 26-33, 2013.

[24] N.R. Mugade, J.B. Sapkale, "Ethnoecological study of mangroves along the estuaries of Rajapur and Devgad tehsils, coastal Maharashtra,” International Journal of Oceans and Oceanography., vol. 11(1), pp. 31-44, 2017.

[25] N.R. Mugade, J.B. Sapkale, "Use of mangrove swamps for agricultural and house construction activities: a study of Devgad and Rajapur tehsils of coastal Maharashtra,” Indian Journal of Science and Technology., vol. 10(23), pp. 1-10, 2017.

\section{AUTHOR PROFILE}

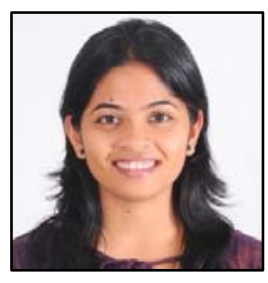

Miss. Nisha R. Mugade is a research student in Shivaji University, Kolhapur and doing Ph.D. under the guidance of Dr. Jagdish B. Sapkale Kolhapur, Maharashtra, India. Area of research: Mangroves, Mangrove ecosystem, man and Environment Relationship, Remote sensing and GIS. Email Id: nrm.geo.rs@unishivaji.ac.in

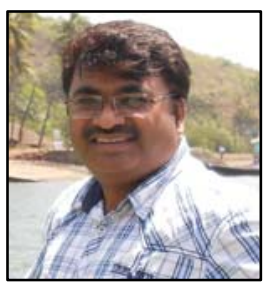

Dr. Jagdish B. Sapkale is working as an Assistant Professor in the Department of Geography, Shivaji University, Kolhapur, Maharashtra, India. He has a research experience of over 20 years in the field of Fluvial Geomorphology, Coastal Geomorphology, Man and Environment relationship and Applications of Remote Sensing and GIS in various Geographical studies. Email Id: sapkalejagdish@gmail.com 